6. Гошко Т. Ян Ласький та перші спроби кодифікації права в Польському Королівстві. Соиіум. 2017. № 13-14. С. 191.

7. Sondel J. Prawo rzymskie jako podstawa projektów kodyfikacyjnych w dawnej Polsce. Zeszyty prawnicze. 2001. № 1. S. 49.

8. Захарченко Петро. Історія українського права: Навч. посібник. К.: ВД «Освіта України», 2019. С. 146-147.

9. Теорія держави і права: підручник. https://pidru4niki.com/70677/ pravo. (Дата звернення: 23.01.21).

10. Uruszczak Wacław. Commune incliti Poloniae Regni privilegium constitutionum et indultuum. O tytule i mocy prawnej Statutu Laskiego z 1506 roku. http://www.law.uj.edu.pl/users/khpp/statut_laski.htm. (Дата звернення: 23.01.21).

11. Uruszczak W. Statut Łaskiego z 1506 roku. 500 lat tradycji państwa prawa w Polsce. Czasopismo Prawno-Historyczne. T. LIX. 2007. Z. 2. S. 13.

12. Uruszczak W. Commune incliti Poloniae Regni privilegium constitutionum et indultuum. O tytule i mocy prawnej Statutu Laskiego z 1506 roku. Zes zyty Naukowe Uniwersytetu Jagiellońskiego. T. XCVI. 2006. Z. 5. S. 113-114.

13. Statut Łaskiego z 1506 r. https://pamiecpolski.archiwa.gov.pl/statutlaskiego-z-1506-r. (Дата звернення: 23.01.21).

14. Зайцева Т. Д. Антропологія міст і міського права на руських землях Корони Польської в XIV - першій половині XVII ст. дис. на здобуття наукового ступеня док. іст. наук. К.: 2019. С. 113-114.

DOI https://doi.org/10.30525/978-9934-26-040-7-5

\title{
ВІЧОВІ ТРАДИЦІї НА РУСІ
}

\author{
Карпічков В. О. \\ кандидат юридичних наук, \\ асистент кафедри теорії та історії права та держави \\ Інституту права
}

Київького національного університету імені Тараса Шевченка м. Київ, Украӥна

Зародження демократичних інститутів і парламентаризму в Україні пов'язують $з$ Давньоруською державою, а саме 3 народним віче, як інститутом прямого народовладдя. Дослідження цього органу має 
важливе значення не лише для юридичної науки, а й для побудови сучасної ефективної системи народовладдя. Більшість існуючих історико-правових досліджень вічових зборів частково розкривають дане питання, що в свою чергу, породжує невизначеність.

Метою дослідження $€$ комплексний історико-правовий аналіз інституту вічових зборів на Русі, його особливостей та місця в системі органів влади.

Окремим питанням діяльності віче присвячені праці відомих українських науковців М. С. Грушевського, Д. I. Дорошенка, М. Ф. Котляра, В. М. Рички, П. П. Толочка, С. В. Кульчицького, Ю. I. Терещенка, С.В. Юшкова, а також праці російських вчених М. Б. Свердлова, В. І. Сергєєвича, В. Й. Ключевського, І. Я. Фроянова, М. М. Карамзіна, Б. Д. Грекова та інших вчених.

Інститут прямого народовладдя існував на давньоруських землях ще в часи родоплемінного ладу, коли головним самоврядним органом стародавніх слов'ян були збори племені - віче, на яких вирішувались найважливіші питання. Вічові збори були засновані на традиціях військової демократії, а участь в них приймали усі дорослі чоловіки племені, які могли тримати в руках зброю. В мирний час цей орган обмежував владу вождів, яким належала вся повнота влади у воєнний час $[1$, с. 25.]. Оскільки в додержавний період центральні та місцеві органи влади розвивались на основі племінної організації, то правляча верхівка i населення прагнули зберегти назву традиційних органів i принципи їх діяльності. До $\mathrm{X}$ ст. на давньоруських землях існували чисельні міста і села, мешканці яких користувалися автономією у вирішенні адміністративних і господарських питань за допомогою віче.

В період становлення державності на Русі роль і значення віче було суттєво послаблене владою Великого князя, адже за десятковою системою управління у містах зосереджувалось в руках воєвод князівської дружини [2, с. 45]. Особливої різниці між містами і селами тоді не існувало, а їх самоврядним органом були вічові збори, в яких приймали участь голови родів і старійшини громади. Віче скликались за потреби та вирішували питання про перерозподіл землі, охорону святилищ, розглядали спори між родами і громадами, виносили судові вироки, піклувались обороною міста та обирали старосту, а їх рішення приймались шляхом досягнення згоди між учасниками [3, с. 34-35].

Після адміністративної реформи, яка відбулась у Х ст. на Русі, система місцевого самоврядування дещо змінилася. На давньоруських землях оформилась багаторівнева система територіальних громад, в якій можна виокремити три основні ланки: громади старших міст, громади підпорядкованих їм молодших міст (передмість) і сільські 26 
громади (верви) [4, с. 539]. Самоврядним представницьким органом старшого міста було віче, а правом брати в ньому участь наділялись вільні члени міської громади - голови великих сімей (родів) та міське боярство. Мешканці прилеглих до міста околиць теж могли приймати участь у зборах, а також князі, бояри і представники вищого духовенства. Юрисдикція віче старшого міста поширювалась на всіх правоздатних членів його громади, жителів молодших міст і верв, а їх рішення були обов'язковими до виконання по всій волості. Віче збирались за потреби, або у випадку військової загрози. Ініціаторами їх скликання були князі, представники вищого духовенства, бояри, а також члени громади. Зазвичай збори проходили на торгівельній площі, князівському або церковному подвір'ї. Достеменно не відомо чи мали вічові збори чіткий регламент, однак відомо, що рішення на них приймались схваленням або запереченням пропозицій учасників, а перевага надавалась тій пропозиції, яку підтримувала більшість учасників, або у підтримку якої лунали найголосніші вигуки [1, с. 25]. На вічових зборах старшого міста обговорювались і вирішувались найважливіші питання, обирались посадники для молодших міст, волостель і міські посадовці (тисяцький, соцькі). Окрім того, віче старого міста вирішувало питання війни та миру, розпоряджалось князівським столом, землями і фінансами волості, приймало місцеві закони, обирало представників князівської адміністрації, піклувалось обороною землі, а також розглядало судові спори. Без згоди віче старшого міста князь не міг провести мобілізацію земського війська. На основі їх рішень приймались рішення віче громад молодших міст $[3$, c. 35].

Самоврядування молодших міст (передмістя) було організоване за тим же принципом, що й у старших, щоправда головним носієм публічної влади при цьому виступала громада старшого міста, в руках якої зосереджувалась примусова влада по відношенню до жителів передмість і волості загалом, адже рішення віче старшого міста були для них обов'язковими. Залежність молодших міст від старшого виявлялось і в тому, що вони приймали від нього посадників.

$3 \mathrm{X}$ ст. на давньоруських землях існували чисельні сільські громади - верви, які визнавались самоврядними територіальні одиницями. До складу кожної верви входило десять і більше сімей 3 одного чи декількох родів, які вели спільне господарство. У сільських громадах важливі питання теж вирішувались за допомогою віче, в якому брали участь голови дворів (родів і великих сімей), а їх компетенція була аналогічною до вічових зборів у містах [5, с. 71]. 
3 XI ст. старші міста перетворювались на політичні центри князівств, а авторитет місцевих (удільних) князів багато в чому залежав саме від підтримки міської громади і віче. Як орган прямого народовладдя, віче мало дуже широку владу - законодавчу, виконавчу та судову, а до їх компетенції належало прийняття місцевих законів, санкціонування міжкнязівських договорів, припинення міжусобиць, тощо. Окрім того до повноважень віче належало обрання єпископа, а також покликання (запрошення) та вигнання князів. Обираючи князя, віче старшого міста, заключало з ним договір - «ряд», порушення якого тягло за собою настання небажаних для першого наслідків. Якщо новообраний князь зловживав владою, чинив свавілля, або ж вчиняв злочин, то місцева громада могла позбавити його влади, вигнати 3 міста, а інколи навіть стратити [6, с. 215]. Історії відомі випадки, коли відмова князя задовольнити вимоги віче призвела до погрому князівського двору та вигнання його 3 міста. Заключаючи такий договір, народ встановлював «умови князювання», що слугувало механізмом «стримувань i противаг», оскільки збалансовувало відносини між ним і князем, звільняючи їх від чіткого ієрархічного підпорядкування [7, с. 142-144]. Подібний розподіл владних повноважень між князем і віче підштовхує до думки, що обсяг їх влади був майже однаковий.

До XII ст. на більшості давньоруських земель князівська влада контролювалася народом за допомогою вічових зборів. На відміну від князів, які змінювались, віче було незмінним постійно діючим демократичним органом. Князь не міг просто проігнорувати рішення віче, адже не дивлячись на те, що термін князювання формально вважався довічним, однак на практиці він залежав від визнання князя народом, а також від правильного розпорядження ним владою [6, с. 215]. Тому цілком справедливо можна стверджувати, що віче виступало механізмом протидії тиранії князів і обмежувало князівську владу, не даючи їй стати абсолютною. Проте, вплив народовладдя на давньоруських землях не був однаковим. Там, де князівська влада була сильнішою, віче могло бути інструментом політики князя. На землях де влада князя була слабшою, він, навпаки, міг бути залежним та підзвітним вічовим зборам [8, с. 34-35].

В період феодальної роздрібненості, за правління тріумвірату (дуумвірату) Великих князів, аж до першої половини XII ст. віче все ще мало істотний вплив на управління державою, але все більше представляло інтереси міського боярства, а самі вічові збори вже не були схожими на класичний орган прямого народовладдя [2, с. 56]. 
Отже, з урахуванням вищезазначеного, можна зробити висновок, що віче існувало ще в додержавний період і впродовж всього часу існування Давньоруської держави, виступаючи інститутом прямого народовладдя. Те, що у вічових зборах брали участь місцеві князі, вище духовенство та боярство, наштовхує на думку, що віче можна віднести до найвищих органів влади того часу. Окрім того, віче виступало механізмом протидії тиранії князів, оскільки обмежувало князівську владу і не давало їй набути абсолютного характеру. Хоча з другої половини XI ст. міське віче представляло здебільшого інтереси боярства, прості люди все ж таки могли виступати на вічових зборах $\mathrm{i}$ мали реальну змогу бути почутими владою.

\section{Література:}

1. Пресняков А. Е. Княжое право в древней Руси. Очерки по истории X - XII столетий : исторические очерки. Санкт-Петербург : Типография М. А. Александрова, 1909. 316 с.

2. Карпічков В. О. Становлення та розвиток органів місцевої влади в Давньоруській державі. Актуальні проблеми держави $і$ права : Збірник наукових праць. Національний університет «Одеська юридична академія». Одеса : Гельветика, 2020. Вип. 88. С. 44-65.

3. Институты самоуправления: историко-правовое исследование / В. Г. Графский и др. ; под ред. Л. С. Мамут. Институт государства и права РАН. Москва : Наука, 1995. 301 с.

4. Яхшиян О. Ю. Крестьянская община и местное самоуправление в России. «Российская государственность: традиции и вызовы ХХІ века». Материаль Всеросс. науч.-обществ. конф., Великий Новгород, 19 сентября 2012 г. Москва : Научный эксперт, 2013. C. $538-551$.

5. Надолішній П. I. Вітчизняна традиція демократичного врядування як аспект національного державотворення: до 360 річниці конституції Пилипа Орлика. Вісн. держ. служби Украӥни, 2009. № 4. С. 69-78.

6. Свердлов М. Б. Домонгольская Русь: Князь и княжеская власть на Руси VI - первой трети XII в. : монография. Санкт-Петербург : Академический проект, 2003. 736 с.

7. Спадщина поколінь. Прадавні українські літературні пам'ятки. Повість минулих літ : навч. посібник. Київ : Грамота, 2005. 591 с.

8. Толочко П. П. Київська Русь. Київ : Абрис, 1996. 360 с. 